\title{
Role of public archivists in post-apartheid South Africa: passive custodians or proactive narrators
}

Isabel Schellnack-Kelly

University of South Africa

Department of Information Science

Tel: +27124296936

E-mail: schelis@unisa.ac.za

\begin{abstract}
This paper explores the conflicting roles of archivists in the execution of their archival mandates in directing the management, preservation and disposition of current public records. A comprehensive understanding of the dynamics being encountered by the South African public archivists contextualises the conditions in which these officials provide guidance to the current dispensation. A post-modernism approach and Frank Upward's Australian continuum model ${ }^{1}$ have been explored and contextualised in the milieu of post-apartheid South Africa. The article proposes a two-pronged strategy for a more comprehensive approach from the public archivists and their interactions with the records management practitioners, by applying Oliver and Foscarini's record keeping informatics pyramid. ${ }^{2}$ Firstly, public archivists and practitioners should have as their objective the formulation of effective solutions which consider the skills, knowledge and expertise of officials tasked with the responsibilities of implementing and maintaining the records management systems. Secondly, the archivists and the records practitioners need to ensure that they equip themselves with knowledge that enables them to have broadened, contextualised understanding of the environmental parameters within which the information sources need to be utilised by the current dispensation. Public entities must be able to find the information sources required to address poverty, support sustainable development undertakings and the National Development Plan. These sources must also serve purposes such as justice, providing evidence of transparency and accountability.
\end{abstract}

Keywords: postmodernism, metanarrative, archives, records management, information culture, record keeping systems, records continuum model 


\section{Introduction and background}

The $21^{\text {st }}$ century South African public archivists inherited a positivist approach to addressing the management of current records still in the custody of the public entities. The role of this public official was characterised as co-narrator of the apartheid dispensation, in which the roles of records managers and records officials as well as the information management systems was clearly defined and, for the most part, utilised by the public offices as records' indexing tools. Record keeping systems, referred to as filing systems, were approved by the head of the public archival institution and legislatively referred to the State Archivist. Any changes that were made to the systems were discussed and formally approved by the State Archivist. Public entities obtained permission, referred to as disposal authorities, on what records could be destroyed or transferred to the public archival facilities. Although as mentioned by several commentators, like Harris ${ }^{3}$ and Allan ${ }^{4}$ on the South African archival matters, in the transition to a democratic dispensation unauthorised destruction did occur, these records were primarily related to security and administration of justice. Nevertheless, the records not deliberately destroyed provided light to address past imbalances and address issues such as land claims, the Truth and Reconciliation Commission, miners affected by asbestos and silicosis.

Under the pre-1994 dispensations by and large, public offices were meticulous in creating and managing the records, which related to the construction of dams and related infrastructure, as has been highlighted by Tempelhoff, in the significance of the Waterlit Collection at the South African Council for Scientific and Industrial Research. ${ }^{5}$ Local governments, particularly in the province of Gauteng, were able to manage and find their records for the purposes of ensuring business continuity, dealing with the maintenance and upgrading of infrastructure and addressing prospects for development and economic growth. ${ }^{6}$ Sufficient documentation was managed for individuals from the white community to query billings related to the provision of basic utilities.

This article addresses the dynamics which currently impede the efficiency of records management systems and the current trends concerning the management of all information sources, which have been observed and commentated on from various concerned scholars. ${ }^{7}$ In addition, the worrisome phenomena affecting many public entities relates to the low-key status assigned by the post-1994 dispensation, in acknowledging the importance of records as evidence of governance, transparency and accountability, is expanded on. The most glaring 
evidence of this scenario is disclosed in the reports from the Auditor-General of South Africa (AGSA). These reports periodically document the status resulting from the lack of reliable, authentic evidence for the purposes of auditing. Governance, transparency and accountability are fundamental elements of South Africa's constitution and are crucial in a fledgling democracy to create conditions conducive to nation building and generating confidence from both citizens and external observers. ${ }^{8}$ The narratives contained in these reports reveal concerns which have socio-economic and socio-political ramifications, consequentially resulting in frustrations from communities related to poor service delivery. The lack of reliable records to ascertain and report on the utilised of financial resources and others is worrisome. Despite this, limited interventions seem to be instituted by the public archivists, whose efforts are curtailed by the low status assigned to the public archival institutions and hampered by the allocation of limited financial and human resources. ${ }^{9}$

The violent nature of service delivery protests, the general mistrust from the public with regard to the utilisation of public revenue and expenditure and widespread social anarchy are regular features. The correlations to the poor access to reliable information appear to largely go unnoticed and unattended by the public archivist. Although efforts have been introduced by the AGSA office by regularly conducting awareness campaigns on the importance of record keeping, managing the records and ensuring their accessibility during auditing processes; these endeavours appear to have limited impact. ${ }^{10}$ In recent years, due to poor funding and adequate human resources the public archival institutions, both at national and provincial levels, appear unable to provide workable solutions to address the situation and become active participants in shaping and changing the narrative being revealed in the AGSA reports. Assuming the role of passive custodians, by having its wings clipped by inadequate resources, the public archivists are poorly equipped to provide coherent solutions to effectively manage public records, or adequately fulfil its cultural heritage function as a storage facility for public records. ${ }^{11}$ Currently, the public archival institutions are unable to accommodate new accessions and poorly equipped to adequately deal with electronic records. $^{12}$

\section{Purpose of article}

The aim of this article is to challenge the current South African dispensation to acknowledge the importance of records for the purposes of providing factual evidence of governance and openness, particularly in the case of the AGSA reports. The current dispensation likewise 
needs to realise that access to data and information is also crucial in developing solutions to tackling poverty, creating opportunities for sustainable development and effectively addressing past imbalances and discrimination. Endeavours like the National Development Plan, which includes strategies by local governments to address issues such as urban sprawl, ${ }^{13}$ all require the public archivists to become active participants and demonstrate their relevance when approving the record keeping systems and determining the fate of the records. The importance of data and information in digital format cannot be denied and requires vigilant interventions to ensure that public archivists are regarded as active participants in the country's narratives, and not merely as passive custodians. Better interactions from the public archivist would safeguard their contribution and prevent their roles from dwindling.

Applying Oliver and Foscarini's information culture pyramid model ${ }^{14}$, this article will firstly unpack their relevance to the South African public sector records management practices. Oliver and Foscarini identified three factors which impact on the information culture being: records, information preferences, language consideration and technological infrastructures; information-related competencies and awareness of officials working with information sources; and information technology governance and trust. ${ }^{15}$ Secondly, this article seeks to examine the applicability of the Australian continuum model on South Africa's public sector record keeping practices. In addition, the article will explore the possibility of utilising this model to create conditions conducive for SA local governments to effectively address and enhance socio-economic development by providing milieus which support sustainable development, address poverty eradication endeavours, deal with urban sprawl, environmental concerns, service delivery and infrastructure. All of which are integral to improving the attainment of the National Development Plan by 2030. ${ }^{16}$ Thirdly, in this article, the aptness of postmodernism on the SA archival discourse and its relevance in information preferences and the language which has influence the strategies, policies, procedures and outcomes in post-apartheid South Africa are brought under the microscope.

The post-1994 South African dispensation, being freed from international isolation, enabled the country's archivists to consider other models than the positivist paradigms which had characterised the public archival services since the 1950s. In the $1990 \mathrm{~s}$ and early $21^{\text {st }}$ century, ventures have been undertaken to align the public archival services in line with international trends advocating governance and trust associated with the management of 
records and archives. In addition, attempts have extended to acknowledging the importance of observing international standards, such as ISO 15489, and the theoretical correlations regarding accessibility and disposition of archives and records with accountability, transparency and security are largely acknowledged in the public archival service's policy documentation regarding records management practices in public bodies. ${ }^{17}$

Well-constructed interventions are required to tackle status quo regarding public sector information management which include "information-related competencies" 18 such as the skills, knowledge and expertise of individuals involved in the execution of developing, implementing and disposition activities associated with the recordkeeping systems. Skills, knowledge, language and numeracy, coupled with information technology literacy challenges are mitigating factors of which archivists, records managers and other associated ARM practitioners should be cognisant. ${ }^{19}$ With these factors in mind, appropriate records management solutions should serve a wider audience, namely the country's citizens, and enable, using local governments as an example, each public entity to access information required to eradicate poverty, develop and maintain infrastructure, address urban sprawl and create conditions that support endeavours for sustainable development. Simultaneously, constitutional requirements for evidence to be available to demonstrate transparency, accountability and trust cannot be neglected.

\section{Literature review}

The identified themes have been correlated with relevant literature concerning information culture, continuum model and postmodernism. These have been integrated with recent South African studies relating to records management practices in public entities.

\subsection{Information culture}

A qualitative study conducted by Oliver and Foscarini, contended that an information culture is present in all entities. The phenomenon is not confined to specific nationalities or countries but, rather to the record keeping informatics bestowed by individual entities concerning the representation, processing and communication of information by means of natural and artificial systems. ${ }^{20}$ The study further contended and illustrated how the information culture can is determined by three factors. ${ }^{21}$ These, in turn determine the effectiveness of the records management programmes embarked upon by individual entities, 
and this is similarly applicable on the entities of South African local government and the public archival institutions.

The first factor is the value that entities bestow on information sources to provide credible evidence and ensure business continuity. This value ultimately influences the development and implementation of appropriate strategies, policies and procedures. In addition, these interventions need to be cognisant of language considerations and technological infrastructure. Observance and execution of relevant laws, regulations and standards, coupled to the behaviour and attitude of all users concerning the treatment of information sources will reveal the effectiveness of the records management programmes. ${ }^{22}$

The second factor is "Information-related competencies" 23 regarded as the knowledge held by different users to create, manage, preserve and disseminate the information, regardless of format or medium. ${ }^{24}$ Public sector records officials and records managers, in the execution of their records management tasks, need to direct their attention to protecting records as evidence. Meanwhile, the public archivists in a collaborative role should provide focussed search and retrieval tools to effectively satisfy a broader audience. This second factor, referring to the skills, knowledge and expertise of the various role-players of effectively formulating, implementing and approval of appropriate records management solutions, including the record keeping systems, is particularly relevant in the context of South African public bodies. Local governments, like other public bodies, are required by archival legislation to have their tools formally approved by the relevant provincial archivists. ${ }^{25}$ Education and digital literacy, essential to the outcome of records management programmes, and in the South African context may be regarded as influencing factors with regard to access and the effective management of information sources. These factors have been identified as areas of concern in South African studies. ${ }^{26}$

The last factor affecting the information culture involves IT governance and trust. ${ }^{27}$ This factor relates to trust issues demonstrated within entities towards the record keeping systems for information sources, of any format or medium. In addition, IT governance and trust are a mitigating dynamic for archivists and records managers to have more collaborative roles. These roles should not only be with each other but, also with all the others users in order to provide strategies and tools that ensure their relevance in the information management realm. Technology has resulted in more creators and users able to create tools and solutions to 
ensure they find the information they seek. The result is that the role of the records managers and archivists may become increasingly side-lined. In recent years, many South African narratives of records irretrievable when requested or destroyed without formal instructions, or in accordance of any authorised National Archives disposition authority, have been documented by several scholars. ${ }^{28}$ In addition, are the ineffective efforts of implementing EDRMS where doubt, uncertainty and fear, coupled with the low value bestowed on the management of information sources and information-competencies, consequently results in the ineffective use of the technology. ${ }^{29}$

Records management scholars emphasise the importance of recorded evidence for the optimal operational functionality of any organisation. Emphasis is also attracted to the reliable retention of memory resources to prevent organisations from coming to a complete standstill, in the event of a terror attack or natural disaster where human resource memory, termed "vital records" may be irreplaceably lost. ${ }^{30}$ Scholars such as Ngoepe contend that information management, and more specifically records management is advocated to entities as being significantly important to safeguard and ensure the proficiency of the entity. This function should therefore be assigned identical status to that assigned to the management of capital, financial and human resources. Credibility is also given to associating records as evidence of business processes. Furthermore, it is important to understand the processes that create the evidence and how the information enables the organisation to fulfil its mandates and legal and financial obligations, and facilitate business operations. ${ }^{31}$

\subsection{Continuum model}

Frank Upward's records continuum model directs the spotlight on the nature of "recorded information as an authoritative resource." ${ }^{32}$ Upward further surmises that the trust bestowed on information sources is determined by the manner that they were created and whether their provenance has been retained. The information systems, be they record keeping systems for paper-based information sources or EDRMS for electronic records are "instruments of power" 33 and will ultimately determine what will be remembered or forgotten. Nesmith contends that the archive will form regardless of interventions to manage the information sources. He further argues that information sources and record keeping should be activities that enable the information sources to provide evidence in ascertaining the efficacy of service delivery and utilisation of financial resources. ${ }^{34}$ These are in essence, the performance outcomes that the South African Auditor-General reports are revealing. These AGSA 
reports, thereby demonstrate how narratives revealed by the information sources, including the lack thereof, are not purely in the domain of the public archivists and records manager but, with the auditors.

The records continuum model requires the archivist to develop innovative ways of understanding the information requirements of different users, particularly when involved with advising on the formulation of the record keeping systems. The archivist needs to be more aware of the transdisciplinary nature of information and engage with the interdisciplinary boundaries facilitated through access to the information. ${ }^{35}$ Lyotard contends that "all members of society should have appropriate access to the information required to achieve their mission and objectives." ${ }^{36}$ While Iacovino has applied the records continuum model to analyse the relationship between record keeping system and their role in facilitating access to information for legal matters. ${ }^{37}$ The continuum model is also the basis of the study conducted by Oliver and Foscarini related to the information culture framework. ${ }^{38}$

\subsection{Postmodernism}

Scholars like Ketelaar ${ }^{39}$, Brothman ${ }^{40}$, Harris ${ }^{41}$, Cox $^{42}$, Nesmith $^{43}$ and Derrida ${ }^{44}$, challenge the achievement of neutrality and objectivity by the archivist. Further contentions are on the role of language and lexicology in gaining or controlling access to the information contained in, and shaping the narrative revealed, in the information sources, regardless of format or medium. ${ }^{45}$ One of the pioneering international archivists to post-apartheid South Africa was Canadian archivist, Terry Cook. He encouraged archivists to redefine their roles in order to remain relevant and actively participate in discussions, debates and the processes involving the management and care of electronic records. ${ }^{46}$

The archive, according to Derrida ${ }^{47}$ and Foucault ${ }^{48}$, is linked to storytelling. Derrida contends that the archive is a construction created from, and an expression of, power. The archivist is thus assigned the powers to control and determine the memory by collecting the archive. $^{49}$ The archive can be composed from collections of documents, records, images, data and personal recollections from people and their relations to power. ${ }^{50}$ These information sources are then selected, assembled, arranged, described and interpreted to formulate the narratives. ${ }^{51}$ These narratives can be in the form of annual reports, auditor reports, web and social media home pages, and viewed as the official narrative, or metanarrative, that the entities want revealed to interested audiences. The archon power associated with "drafting, 
destruction and dissolution" of information sources implies that archivists and other users, including records managers, executives, management echelons, auditors and legal representatives all contribute to composing the narratives through the preservation, disclosure, destruction and accessibility of information sources. ${ }^{52}$ However, the reproduction, dissemination and accessibility to information resources in the digital age challenges the previous positions of power assigned to the archivist. ${ }^{53}$

According to Foucault, the archive is the "law of what can be said, the system that governs the appearance of statements as unique events." 54 Like a narrative, the archives are thus not impartial locations where information sources automatically accumulate. ${ }^{55}$ Thus, as contended by Eichhorn ${ }^{56}$, Derrida ${ }^{57}$, Foucault ${ }^{58}$ and Lynch $^{59}$, both concepts (the archive and metanarrative), were created and recreated by writers and readers when selecting, assembling, arranging, describing, removing and interpreting an available information source, including existing gaps. The gaps provide interpretative flexibility to create and recreate the narratives, including the metanarrative to defend decisions and consequences from possible interrogations and investigations. ${ }^{60}$

In official investigations, like commissions of inquiry, collections of information sources are consulted to uncover historic events and implicate perpetrators. ${ }^{61}$ The metanarrative to defend actions and apportion responsibility is determined by collecting, analysing, evaluating and recording information from accessible information sources while spaces appearing in the lack of information sources are filled with personal recollections. In other words, as contended by Schwartz, archivists and archival establishments support the designated sociopolitical values, ideas, promises and obligations of their dispensation. ${ }^{62}$ This article contends that the creation, management, preservation and disposal of all information sources reflect the socio-political values, ideas and obligations of all the creators and users. ${ }^{63}$ The records managers, executive and management components, auditors and legal representatives all participate in the production and control of information sources, thereby determining the metanarrative of the public entity and state. ${ }^{64}$

The metanarrative is determined by the description of information sources that orchestrate how the creators, records managers and archivists will contribute to the elements composing the official melody. ${ }^{65}$ Despite being instruments of control and power, these information sources simultaneously serve as instruments of "empowerment and liberation."66 Thus, the 
notion of the archive and metanarrative challenge the South African public archivists and their symbiotic partners, the records managers to:

i) Consciously acknowledge the subjectivity involved in the selection of descriptions for information sources. Prime examples are the approved file plans and records management systems for records of paper, electronic and micrographic media. ${ }^{67}$

ii) Be cognisant of the contributing role of language on controlling and restricting access, transparency and openness to information sources. ${ }^{68}$ Meanwhile, the endusers - the general public - experience challenges of accessing reliable, authentic information required to improve and provide sustainable socio-economic opportunities. The information is also required to ensure access to basic services like water, electricity, sanitation, housing, infrastructure, health care and education.

iii) $\mathrm{Be}$ aware of their contribution to the "passive, inherited and natural metanarrative" of post-apartheid South Africa. ${ }^{69}$

\section{Current South African practices}

Until the 1990s, the legislation, policies, procedures and practices of the South African state archivists assumed a positivist frame of reference that combined empiricism with rationalism. ${ }^{70}$ Archival concepts were contained within a scientific paradigm. With South Africa's isolation from the international community, little interest in investigating or considering other approaches resulted in many concepts, like appraisal and disposition of information sources, remaining uncontested. ${ }^{71}$ Records were regarded as innocent products of processes that reflected and provided evidence of processes not determined by the public archivists. These role-players were impartial custodians actively shaping the state's collective memory and the archives repositories, preserving that collective memory. ${ }^{72}$

With the advent of the new democratic dispensation, it was essential for the South African archivist to transform in order to adequately participate in the new political dispensation and to become "agents of democratisation."73 Kirkwood further contended this was essential in order to provide long-term operational continuity, institutional accountability and protect citizens' rights. ${ }^{74}$ As with other spheres of interest, after years of boycotts and isolation from the global community, the South African public archivist integrated international trends and practices to the policies and procedures being promulgated to governmental entities, in accordance with archival legislation. ${ }^{75}$ The mid-1990s provided challenges on the effective 
and coherent use of electronic records. Urgently required was the formulation of policies and procedures to reduce the loss of information.

A paradigm shift occurred by archivists who realised for their profession to remain relevant in the information age, the profession had to reinvent itself. The $21^{\text {st }}$ Century archivist has to concede that the utilisation of computer-generated technology and the "information super highway" have become the focal pursuit for knowledge and information. ${ }^{76}$ In essence, archivists actively involved with records management-related processes enable their profession to record (provide evidence) and write their own historical narrative.

Despite the threats from the electronic environment, proactive archivists actively engage with all users and demonstrate adaptability to re-engineer their profession. ${ }^{77}$ Such archivists thereby become key players in sculpting accountability in the information sources. ${ }^{78}$ The records management discourse is reinforced by the formulation, observance and compliance with internationally determined projects, programmes, legislation, laws, standards, software and electronic systems. ${ }^{79}$

\subsection{Description, appraisal and custody}

According to Harris, the South African public archives service was apprehensive about its "traditional appraisal methodology" and its legitimacy within the country's section 41(1)(c) of the Constitution, requiring all spheres of government to provide effective, transparent, accountable and coherent government. ${ }^{80}$ The appraisal methodology utilised by the service had no formal strategic framework and based on its judgement of archival value on individual appraisers' assessments of historical value. ${ }^{81}$ Nevertheless, the archives services was concerned about the excessive volumes of support function-related records, such as human resources and financial and procurement records being preserved. ${ }^{82}$ These records resulted in masses of duplicate records, from all levels of government being transferred to archival holdings. In addition, were the challenges emerging from the country's political transformation, such as:

i) Constraints of financial, human and logistical resources;

ii) Costs associated with adequate storage facilities; and

iii) The tsunamis of government records quickly engulfing archival repositories. ${ }^{83}$ 
During the appraisal process, it is estimated that an average of $15 \%$ of public records from each national, provincial and local government structure were identified as having archival value and consequently recommended for eventual transfer to the state archives repositories. ${ }^{84}$ Several kilometres of records belonging to the previous dispensation needed to be transferred to the government archival holdings in order to create space for the postapartheid government. The South African National Archives tried to formulate a sound appraisal policy based on the macro-appraisal model, distancing itself from their Schellenbergian paradigm. ${ }^{85}$

The incentive for this appraisal approach was, as a methodology, to address the challenges of preserving too many records; reduce the quantity of duplicate records; quell the critics viewing appraisal as an obscure process based on "fuzzy value judgements rather than a clear methodology;" $" 86$ and to reduce the loss of permanently valuable electronic records being deleted or stored in formats unreadable under new technologies. ${ }^{87}$ Schellenbergian methodology still dominates the South African national archives' records management processes. All too often, as noted by Hurley, archivists remain fixated with their predetermined structures and solutions which often clash with realities encountered by records managers, who need to remain flexible and adaptable to the challenges being encountered by their organisation. ${ }^{88}$

\subsection{Awareness of international standards}

The uncertainties and potential challenges posed by creating, managing and preserving electronic media attract more users interested in information management. Users are no longer homogenous, confined to records management staff, records managers, archivists and potential heritage researchers but, include auditors, legal representatives and security establishments. ${ }^{89}$ More users are concerned with security, control and access than merely the safekeeping and preservation of information sources for heritage purposes. Scholars such as Steve Stuckey ${ }^{90}$, Chris Hurley ${ }^{91}$ and McKemmish, Upward \& Reed ${ }^{92}$ encourage a postcustodian approach between the archivists and records managers when tackling the digital records conundrum. Having shaken off the pariah status acquired due to apartheid policies, South Africa more actively interacts with the global community as is evident from the participation in the ICA Principles and Fundamentals Requirements for Records in Electronic Office Environments; ${ }^{93}$ and endorsements of international standards in the archival policies and directives. ${ }^{94}$ 
The development of standards encourage accountability were the stimuli for standards such as: International Standards Organisation (ISO) 15489, focusing on the methodology to design and implement sustainable electronic records management programmes; ISO 15801, concerning the trustworthiness and reliability of the audit trail concerning electronic imaging (copied or scanned versions) of information sources; and ISO 23081, regulating the minimum requirements of metadata required to effectively distinguish information, documentation and records from each other. ${ }^{95}$ All of which have been adopted, often void of contextualisation, by the South African public records management environment. Other initiatives have included the Model Law on Electronic Commerce formulated by the United Nations Commission on International Trade Law; European Union's digital signatures directive; United States Department of Defense's Design Criteria Standard for Electronic Records Management Software Applications for federal agencies; Australia's Recordkeeping Metadata Standard for Commonwealth Agencies; British Standards Institute's principles of good practice for information management, management of optical disc systems for recording documents required for evidence, code of practice for legal admissibility and evidential weight of information stored electronically, and a yardstick workbook designed to gauge compliance with the legal admissibility and evidential weight of electronically stored information. ${ }^{96}$

As contended by Kirkwood, electronic technology lures organisations into false securities concerning accessibility and safe keeping of information sources, without comprehensive records management programmes, policies, procedures and well-formulated record keeping systems. ${ }^{97}$ Furthermore, organisations discover the obstructions pertaining to functional efficiency, validity of the electronic data and legal admissibility of the records. ${ }^{98}$ It is in this context that agreed standards, legislation and concerns have become the cornerstones of the records management milieu, internationally, and in South Africa. ${ }^{99}$ South African public archivists aware of international perspectives on digital records participate in national and international endeavours to formulate strategies to deal with the challenges associated with erecords in the public sector environment. ${ }^{100}$ However, it is questionable whether the public archivists' budgetary and human capacity constraints truly equip them to influence and be significant, accountable role-players. ${ }^{101}$ 
While archival diplomatics clearly defines the roles of the creators, records managers and archivists, it is questionable whether the archivist purely assumes neutral role as custodian and guardian, ensuring the preservation and safekeeping of permanently valuable archives. ${ }^{102}$ This "neutral role" of the archivists, in selecting, assembling, arranging and interpreting information sources are contested by postmodernists, such as Eichhorn ${ }^{103}$ (2008) and this article.

\subsection{Evidence-based Governance and rigorous interventions}

The spotlight on security, access and control of information, particularly electronically generated information was significantly enhanced at the beginning of the $21^{\text {st }}$ century by two events that drew the attention of the global community. The two events also affected popular perceptions towards governance, accountability and transparency. Both the collapse of Enron towards the end of 2001 and the al Qaeda-lead terror attacks in September 2001 on the United States had significant implications on attracting attention to the significance of archivists, records managers and the management of information sources. ${ }^{104}$

The American multinational corporation Enron filed for bankruptcy towards the end of 2001. ${ }^{105}$ This corporation funded operations around the globe attracting vast amounts of capital, while concealing its performance through false accounting, financial misdemeanours, inflated stocks and profits to provide bonuses and raises, while fabricating "a rosy picture of its performance." 106 The deliberate shredding of records by their auditing firm, Arthur Andersen, to conceal the truth about the corporation highlighted the significance of audited financial reporting in attracting investors and the roles of the information managers. ${ }^{107}$ The emergence of Standards of generally accepted accounting practice (GAAP) were in response from investors wanting financial transparency to assess the reliability, integrity, prospects and risks undertaken by entities. ${ }^{108}$ These consequently form the basis of the standards being observed in the auditor reports of the South African Office of the Auditor-General. ${ }^{109}$ Enron's false financial books, falsified reports to complicate understanding and interpretations, and the sale of Enron documentation, like its Risk Management Manual, on eBay also brought into focus the complacent roles of records managers and archivists. ${ }^{110}$ The Enron debacle was attributed to three main culprits: top management, corporate audit committees and Arthur Andersen. ${ }^{111}$ According to Isa (2009), top management were accountable for actions and business operations, and were responsible for the misdemeanours of their subordinates. ${ }^{112}$ The corporate audit committee was dependent on reliable 
information from management, internal and external auditors to investigate and tackle questionable transactions, litigations, risks and contingencies. Arthur Andersen's orchestration of deliberate shredding of supporting documentation and the fabrication of fraudulent information sources highlighted the roles of the records managers and archivists, from mere custodians to accomplices in shaping the entity's facts and narratives. ${ }^{113}$ Records management was this associated with narrative related to corporate governance and elevated to boardroom status. ${ }^{114}$

Meanwhile, security, access and control of information rather than the preservation of information sources for heritage purposes was in reaction to the al Qaeda related terror attacks around the globe being pushed onto the centre stage, with the 9/11/2001 attack on United States. ${ }^{115}$ These events directed the spotlight on records management, allowing it to become the "Coca Cola ... of archival discourse." 116 Specific interest groups from service providers of filing stationery to amateur information technologists, marketing electronic software, clambered on the bandwagon in pursuit of the envisaged fortunes which records management could bring. Inclusion in the global community ensured that South Africa was an overwhelmed participant on the globalisation stage and, similarly, national service providers sought to carve their share of this market. In response to the aftermath of the 9/11 attacks and seemingly related events around the globe, including Kenya and Tanzania, witnessed an intense interest, amongst others, in the effective management, security and control of information sources. ${ }^{117}$ There were concerns from developed nations that funding and aid to developing nations were being redirected to potential paramilitary entities threatening global peace and security is the backdrop for governance, transparency and accountability. ${ }^{118}$ International agencies acknowledged the urgency of promulgating and motivating for strategies to determine levels of governance. Furthermore, the widespread access to information requires legitimate, workable solutions concerning access, security and control over electronically generated information sources. ${ }^{119}$

Concepts such as promoting accountability and transparency were identified by international agencies as essential components which, provided they were upheld by responsive and accountable political and administrative systems, would enable impoverished countries to develop, manage and sustain economic development as well as satisfy the basic social needs of all its citizens. ${ }^{120}$ These entities developed concept models which encouraged impoverished countries to strive for the attainment of sustainable strategies which would 
satisfy the interests of all citizens, as well as promote human dignity, security, justice and equality. Mechanisms in the form of legislation and watchdog organisations were encouraged as enforceable measures to ensure that vital and accurate information could be provided timeously to facilitate effective, transparent decision-making, development planning and governments accountable to citizens. ${ }^{121}$ These concepts, driven by the interests of easing consciences of developed countries concerning impoverished areas around the globe; the attainment of a safer world now fearful of being blindsided by terror attacks; and encouraging the youth of impoverished countries to engage in sustainable economic development opportunities rather than becoming involved in war-mongering activities and/or crime syndicates, have largely formed the incentives (and support) for the Millennium Development Goals.

Sanctioned by funds, programmes and agencies of the United Nations, the World bank, the IMF and the Organisation for economic Co-operation and Development; the Millennium Development Goals (MDGs), to be attained by 2015, were identified by 189 leaders at a United Nations Millennium World Summit in 2000. These eight goals were the elimination of extreme poverty and hunger; promotion of gender equality and empowerment; improvements to maternal health care; reduction of child mortality rates; combatting of communicable diseases such as HIV/AIDS and malaria; safeguarding environmental sustainability; and a global development partnership. ${ }^{122}$

This article contends that the attainment of the utopia of no poverty and sustainable economic development through the MDGs enables the records management discourse and its practitioners, particularly in a developing country like South Africa, to assume a protagonist role by aligning its policies, processes and practices with best practices methodology. Concepts of corporate governance are encouraged by entities responsible for the successful attainment of the MDGs, particularly in impoverished countries. The best practices methodology views processes, practices and systems, performed optimally, to improve the proficiency of organisations. ${ }^{123}$ Records management related legislation (not restricted to archival legislation but, inclusive of those focusing on the management of records or evidence, in whatever form) determines the foundation for accountable and effective governance. ${ }^{124}$ Furthermore, a direct spin-off for public entities having and sustaining sound management, care, retention and disposal of information sources is their proficiency in being able to focus on the attainment of the MDGs within their jurisdiction. Records management 
theorists, such as Heather MacNeil, want record keeping systems to reflect the context within which the records were created and maintained during the active phase; and simultaneously aid in better understanding of the records. ${ }^{125}$ Bearman's articulation for record-keeping systems which considers all users, be they legal practitioners, auditors or medical practitioners, also better enables an organisation to have efficient access to information and provide better service delivery. ${ }^{126}$

This metanarrative may provide incentives for public entities to describe and document the activities of public entities involved with the attainment of the MDGs and in South Africa, those entities, such as local governments, tasked with the attainment of the 2030 National Development Plan. The information sources will reveal narratives where children were afforded education; had access to effective health services, water and electricity, opportunities to participate in sustainable economic development such as those envisaged with Ekurhuleni's Aerotropolis Project; and the nurturing of leaders striving for peaceful coexistence and spiritual enrichment, rather than war-mongering pursuits. Reliable, prosecutable evidence should be attached to the audit trails (both paper and electronic) of intended social upliftment documentary evidence relating to donor funds and resources. As argued by Meijer, the chief objective of records management are strategies to ensure access to information related to the traceability of funds landing up in the coffers of corrupt individuals and/or channelled to terrorist networks and criminal syndicates disregarding the MDGs and intended recipient communities. Reliable, prosecutable evidence should facilitate the narrative for perpetrators to be brought to justice. ${ }^{127}$

\section{Continuum model application in South Africa}

The continuum model that is the foundation of strategies for all formats of information sources was adopted by Australian archivists and records managers. ${ }^{128}$ The essential difference between this model and that of the life-cycle model is the responsibilities assigned to the archivists and records managers, throughout the life cycle stages of the records are intricately linked. ${ }^{129}$ The relationships between the country's public archivists and public sector records managers are key components. The continuum model associates the functions of record creators and all its users, and forms the basis for standards concerning documents, records and archives. ${ }^{130}$ Australia defines these standards as "a consistent and coherent regime for management processes from the time of creation of records (and before creation, 
in the design of recordkeeping systems), through to the preservation and use of records as archives."131 The continuum model views the life cycle stages as linear progressions rather than cyclical, as in the case of the life-cycle model. Furthermore, this model encourages proactive engagements from the archivists and records managers, together, sculpting the record by planning and determining the course of the information management systems to meet the "goals, intentions and assumptions" of the creating entity. ${ }^{132}$ These engagements also determine the disposition fate of the information sources from creation until transfer into archival custody.

The Australian continuum model draws attention to the symbiotic relationship between record keeping processes and "historical recordkeepers."133 The model identifies three groups strategically situated to coordinate recordkeeping and archival processes. The first group are the individuals working with, and in, the records offices. In South Africa these would be referred to as the personnel working in the registries and mailrooms. These offices are ideally equipped with comprehensively formulated record keeping systems to record the executive, administrative, financial and operational activities of the creating entity. ${ }^{134}$ Furthermore, these components create and maintain the control mechanisms related to the information sources being created and stored, such as the Register of Files Opened. ${ }^{135}$ As proposed by McKemmish, Upward and Reed, these persons are the "true archivists" directly involved in the archives creation and receipt stage. ${ }^{136}$ A second group are those working between the records managers and archivists (historical record keepers). The third group are the historical record keepers (archivists) working in the archival facilities. ${ }^{137}$

In South Africa, the current records management policies promulgated by the public archivists support the role performed by all of these players in the creation, management, identification and preservation of information sources. ${ }^{138}$ The officials working in the South African public sector registries and mailrooms are guided by the prescribed National Archives' registry procedure manual. ${ }^{139}$ "Every governmental body which falls under the stipulations of the National Archives of South Africa Act (No. 43 of 1996) is required to compile a Registry Procedure Manual and submit it to the National Archivist for approval . . . The manual . . . must describe . . the registry and records management procedures that are applicable to the body." ${ }^{140}$ This prescribed manual assigns the duties of the administration and supervision of all registry procedures, supervision of registry staff and mailroom staff, their training as well as all related delegated records management tasks to the chief registry official. $^{141}$ 
Meanwhile, the records managers of South African public bodies are assigned overall control, preservation and care of the entities' information sources. In accordance with policy prescribed by the National Archives' Records Management Policy (NARS 2007), these officials manage the activities of staff in the registries, mailrooms, and related areas. Records managers are responsible for the control and access to information sources while they remain at the current and semi-current stages within the jurisdiction of the creating entity. ${ }^{142}$ Furthermore, these public officials are solely accountable for:

i) Controlling the maintenance and application of the approved indexing systems, such as the file plan;

ii) Disposal of information sources, as guided by the section 13(2) of the National Archives Act which stipulates that "no public record under the control of a governmental body shall be transferred to an archives repository, destroyed, erased or otherwise disposed of without the written authorisation of the National Archivist;" 143

iii) Control and preservation of all information sources; and

iv) Training of the registry head. ${ }^{144}$

Public sector records managers are required to ensure their entity complies with the directives, instructions, regulations and guidelines issued by the National Archivist concerning the creation, management, maintenance, disposal and safekeeping of current and semi-current information sources. These directives apply to records regardless of form or medium, including electronic records and microfilm. ${ }^{145}$

The public archivists' roles as custodians, as well as their interactions with the public sector records managers, are promulgated in the National Archives legislation. ${ }^{146}$ The public entity's custodian functions, powers and duties, as promulgated in the Act involve:

i) Preserving records of enduring value for use;

ii) Making these records accessible and promoting their use;

iii) Ensuring proper management and care;

iv) Promoting awareness of archives management, archival activities, preservation and use of the national archival heritage;

v) Establishment of archives repositories for the custody of records; 
vi) Transferring of records of enduring value to archival custody once they have been in existence for 20 years, and may be available for public access; unless the condition of the records is regarded as fragile; and

vii) Undertaking measures to preserve and restore records. ${ }^{147}$

In addition, the National Archives Act, no. 43 of 1996, defines the parameters of the relationship between the public archivists and records managers. These are expanded on in the regulations, policies and guidelines provided in the records management publications of the National Archives. ${ }^{148}$ The relevant functions, powers, duties and responsibilities that are highlighted include:

i) Promoting awareness and encouragement of records management, such as conducting inspections of public records both at the creating entities or records storage facilities;

ii) Involvement in the formulation, approval and maintenance of tools (such as file plans, electronic document records management systems0 aimed at arranging, describing and retrieving information sources;

iii) Providing records management training and cooperating with entities involved in records management and archival pursuits;

iv) Proper management and care of public records in the custody of public bodies, to include appraisal and disposition-related activities and defining conditions of information sources being reproduced electronically or microfilmed.

v) Finally, via current and newly compiled directives and instructions concerning the management and care of public records in the custody of public entities, public sector records managers are responsible for the execution, observation and compliance with the South African National Archives and Records Service Act. ${ }^{149}$

The Australian continuum model further influences South African records management practices by the number of publications issued by the public archivists concerning electronic records, such as Managing electronic records in governmental bodies: Policy Guidelines; and Records Management Policy. ${ }^{150}$ As noted by Bantin, the continuum model regards the archivists and records managers as "intimately involved at all points;" and is the basis of the approach for the management of electronic records. ${ }^{151}$ Hurley $^{152}$ and Stuckey ${ }^{153}$ both advocate the continuum model. Encouragement for the involvement of archivists and records managers in the development, selection and promotion of solutions concerning creation, 
management, disposition and preservation of digital information sources has been instrumental in seeking plausible solutions and the creation of international standards, like ISO $15489 .{ }^{154}$

Applying the continuum model to identifying what metadata should be recorded, also needs to involve the archivists and records managers if their roles are to remain sustainable and not being superseded by information technologists. The importance of South African public sector archivists and records managers being cognisant of the transdisciplinary nature of information and the interdisciplinary dynamics associated with access to information is pertinently illustrated in the Aerotropolis undertakings by the City of Ekurhuleni. The objective of this airport city venture is to promote competitiveness and efficiency attractive to investors and developers wanting to exploit opportunities reliant on air commerce. The venture should boost trade and foster economic development. Interested participants will be users seeking information to facilitate engineering and planning concerning infrastructure and provision of services delivery to all communities, within the municipal boundaries of Ekurhuleni and the province of Gauteng. ${ }^{155}$ This venture needs to boost agricultural practices, support small business undertakings and facilitate rural development. All need to be sustainably undertaken, without exhausting or compromising the City's wetlands, biodiversity and fragile ecosystems. ${ }^{156}$

A few examples of the information or data needing to be created, captured, organised and disseminated to ensure contemporary users involved in ventures associated with Ekurhuleni's Aerotropolis include: geotechnical data such as the identification of dolomite as locations for potential sinkholes, hydrology data and socio-economic data impacting on agricultural practices, heritage sites, development of small businesses and rural diversity, which are all crucial for planning endeavours. ${ }^{157}$ The record keeping system of Ekurhuleni, regardless of the format of medium, must ensure that the information is accessible to a wide network of users. An appropriate EDRMS for this local government entity must ensure that adequate metadata can be incorporated to enable all relevant users to access the information and facilitate the different contexts for which the information, or data, is required.

This article argues that the indexing tools, such as the approved record keeping systems and EDRMS, developed and utilised by public entities, including local governments should be aligned to the government mandates. The public archivists and records managers need to strive for collaborative engagements and understanding with all contemporary users to ensure 
that information can be accessed in order to attain the National Development Plan. ${ }^{158}$ As indicated in the example of Ekurhuleni, local governments are a key component of the National Development Plan. This sector is mandated with addressing matters related to socio-economic development, developing infrastructure and attending to service delivery to local communities. Thus, the information management regimes of the local government need to facilitate access to the data and information required to achieve these.

\section{Conclusion}

In order for South Africa to adequately address the worrisome circumstances concerning the management of public sector information sources for active engagements to address the three concerns expanded on in this article. The first, and most urgent, is the addressing the information culture by dedicated undertakings to enable the "true archivists" in the public offices to attain adequate literacy, numeracy and information technology literacy skills. Not only would this enable these officials to perform more effectively but, also from a humanitarian perspective would ensure that they are not exploited and are able to actively participate in the democratic dispensation, equipped with the necessary knowledge about their constitutional rights. The second is the urgent need for the public archivists and records managers to reprioritise and enhance the value public entities bestow on information sources. Despite initiatives from the AGSA to have gatherings enlightening the public entities on the importance of managing the information, few interventions are undertaken by the public archivists. ${ }^{159}$ And, finally, the public archivist also need to participate in enabling the country to address poverty, encourage sustainable economic development and the attainment of the National Development Plan by ensuring that record keeping systems and the disposition decisions do not compromise public entities from accessing the information required for these purposes. To ensure their longevity, the South African public archivists need to ensure they provide services that serve all South Africans and acknowledge the importance of data and information in enabling the goals and objectives of the post-apartheid constitution in striving towards the attainment of a better life for all South Africans, and particularly those from previously disadvantaged communities.

\footnotetext{
${ }^{1}$ Upward, Continuum Mechanics and Memory Banks, 84-109.

${ }^{2}$ Oliver and Foscarini, Records Management and Information Culture, 16.

${ }^{3}$ Harris, Archives and Justice.

${ }^{4}$ Allan, Paper wars.

${ }^{5}$ Tempelhoff, History of the Waterlit Collection, pp. 162-183.
} 
${ }^{6}$ Schellnack-Kelly, The role of records management in governance-based evidence.

${ }^{7}$ Ngoepe, An exploration of records management trends.

Makhura, The role of electronic records management.

Marutha, Records management in support of service delivery.

${ }^{8}$ Schellnack-Kelly, The role of records management, 4.

${ }^{9}$ Archival Platform, The State of the Archives, 89.

${ }^{10}$ Ibid., 84.

${ }^{11}$ Ibid., 71.

${ }^{12}$ Ibid., 62.

${ }^{13}$ Qwabe, Realising South Africa's Vision 2030, 21-22.

Kelly, Over the Edge: the impact of urban sprawl.

${ }^{14}$ Oliver and Foscarini, Records management and the information culture.

${ }^{15} \mathrm{Ibid}$.

${ }^{16}$ Qwabe, Realising South Africa's Vision, 34.

${ }^{17}$ National Archives, Records management policy.

${ }^{18}$ Oliver and Foscarini, Records management and the information culture, 17.

${ }^{19}$ Ibid., 18-19.

${ }^{20}$ Ibid., 15.

${ }^{21}$ Ibid., 18-19.

${ }^{22}$ Ibid., 35-42.

${ }^{23}$ Ibid., 91 .

${ }^{24}$ Ibid., 91-99.

${ }^{25}$ Schellnack-Kelly, The role of records management, 123-125.

${ }^{26}$ Makhura, The role of electronic records management.

Research Focus and Content-at-Work, The demand for and supply of skills, 65-66.

${ }^{27}$ Oliver and Foscarini, Records management and information culture, 15.

${ }^{28}$ Ngoepe, Exploration of records management.

Makhura, The role of electronic records management.

Marutha, Records management in support of service delivery.

${ }^{29}$ Oliver and Foscarini, Records management and information culture, 145.

${ }^{30}$ Australian Capital Territory Records Office. Guidelines for records, 6, 13.

${ }^{31}$ Ngoepe, An exploration of records management, 5.

${ }^{32}$ Upward and Stillman, Community Informatics, 12.

${ }^{33}$ Ibid.

${ }^{34}$ Nesmith, Re-exploring the continuum, 35.

${ }^{35}$ Upward, Continuum Mechanics, 87.

${ }^{36}$ Ibid., 87.

${ }^{37}$ Ibid., 24.

${ }^{38}$ Oliver and Foscarini, Records management and information culture, 12-13.

${ }^{39}$ Ketelaar, Archives of the people, 5-16.

${ }^{40}$ Brothman, Afterglow: concepts of records, 311-342.

${ }^{41}$ Harris, Archives and Justice.

${ }^{42} \mathrm{Cox}$, Archives and Archivists.

Cox, Ethics, Accountability and Recordkeeping.

${ }^{43}$ Nesmith, Re-exploring the continuum, 35-37.

${ }^{44}$ Derrida, Archive Fever.

${ }^{45}$ Hedstrom, Archives, Memory and Interfaces, 43.

${ }^{46}$ Cook, What is past is prologue, 17-63.

${ }^{47}$ Derrida, Archive Fever.

${ }^{48}$ Foucault, Archeology of knowledge.

${ }^{49}$ Allan, Paper Wars, 206.

${ }^{50}$ Eichhorn, Archival Genres, 3.

${ }^{51}$ Ibid.

${ }^{52}$ Lynch, Archives in formation, 71.

${ }^{53}$ Ibid., 75-76.

${ }^{54}$ Eichhorn, Archival Genres, 2.

${ }^{55}$ Ibid.

${ }^{56}$ Eichhorn, Archival genres, 1-10.

${ }^{57}$ Derrida, Archive Fever. 
${ }^{58}$ Foucault, The Archeology of Knowledge.

${ }^{59}$ Lynch, Archives in formation.

${ }^{60}$ Ibid., 71.

${ }^{61}$ Ibid.

${ }^{62}$ Schwartz, Records of simple truth, 85 .

${ }^{63}$ Ibid.

${ }^{64}$ Ibid.

${ }^{65}$ Harris, Archives and Justice, 86, 207.

${ }^{66}$ Ketelaar, The Panoptical Archives, 145.

${ }^{67}$ National Archives, Records management policy, 55.

${ }^{68}$ Harris, Archives and Justice, 260.

${ }^{69}$ Cook, Remembering the Future, 174.

${ }^{70}$ Harris, Archives and Justice, 120-121.

${ }^{71}$ Ibid., 134.

${ }^{72}$ Ibid., 11.

${ }^{73}$ Kirkwood, Records management in the public sector, 13.

${ }^{74}$ Ibid.

${ }^{75}$ National Archives, Records Management Policy.

${ }^{76}$ Stuckey, Keepers of the fame, 47.

${ }^{77}$ Cox, Archives and Archivists, 7.

${ }^{78}$ Trace, What is recorded, 140.

${ }^{79}$ Harris, Archives and Justice, 120.

${ }^{80}$ Ibid., 85.

${ }^{81}$ Cox, Archives and Archivists, 7.

${ }^{82}$ Harris, Archives and Justice, 92.

${ }^{83}$ Ibid., 93-94.

${ }^{84}$ Ibid., 87-88.

${ }^{85}$ Ibid., 97-98.

${ }^{86}$ Ngulube, Archival Appraisal, 250.

${ }^{87}$ Kirkwood, Records management, 12.

${ }^{88}$ Hurley, What, if anything, is records management, 14.

${ }^{89}$ Cox, Ethics, Accountability and Recordkeeping, 231.

${ }^{90}$ Stuckey, Keepers of the fame.

${ }^{91}$ Hurley, What, if anything, is records management.

${ }^{92}$ McKemmish, Upward and Reed, Records continuum model, 4449.

${ }^{93}$ National Archives website.

${ }^{94}$ National Archives, Records management policy.

${ }^{95}$ Venter, National Archives and Records Service Requirements, 22-26.

National Archives, Managing electronic records.

${ }^{96}$ Harris, Archives and Justice, 117-118.

${ }^{97}$ Kirkwood, Records management in the public sector.

${ }^{98}$ Ibid., 22.

${ }^{99}$ Griffin, Records Management Capacity, 71.

${ }^{100}$ National Archives website.

${ }^{101}$ Department of Arts and Culture, Annual Report 2009/2010.

Department of Arts and Culture, Annual Report 2011/2012.

102 Trace, What is recorded, 138-139.

${ }^{103}$ Eichhorn, Archival Genres, 1-10.

${ }^{104}$ Cox, Archives and Archivists, 91.

${ }^{105}$ Healy and Palepu, The fall of Enron, 3.

${ }^{106}$ Ibid., 9.

${ }^{107}$ Ibid., 10-11.

Isa, Records management and accountability, 63.

${ }^{108}$ Healy and Palepu, The fall of Enron, 63.

${ }^{109}$ Office of the Auditor-General, Consolidated General Report.

${ }^{110}$ Cox, Archives and Archivists, 104, 208.

${ }^{111}$ Healy and Palepu, The fall of Enron, 3.

${ }^{112}$ Isa, Records

${ }^{113}$ Cox, Archives and Archivists, 208. 
${ }^{114}$ Isa, Records management and accountability, 63.

${ }^{115}$ Cox, Ethics, Accountability and Recordkeeping.

${ }^{116}$ Harris, Archives and Justice, 123.

${ }^{117}$ Meijer, Transparent Goivernment, 67.

${ }^{118}$ International Monetary Fund, The IMF's approach to promoting good governance.

${ }^{119}$ Ibid.

${ }^{120}$ Ibid.

${ }^{121}$ Ibid.

${ }^{122}$ United Nations Human Rights office of the Commissioner of Human Rights, Human rights and the Millennium Development Goals, 1.

${ }^{123}$ United States General Accounting Office, Best Practices Methodology, 6.

${ }^{124}$ Roper and Miller, Managing Public Records, 7-10.

${ }^{125}$ MacNeil, Trusting Records.

${ }^{126}$ Harris, Archives and Justice, 138, 140.

${ }^{127}$ Meijer, Transparent government, 67-78.

${ }^{128}$ McKemmish et al. Records Continuum Model, 4449.

${ }^{129}$ Bantin, Understanding Data, 5.

${ }^{130}$ Flynn, The records continuum, 144.

${ }^{131}$ Ibid.

${ }^{132}$ Trace, What is recorded, 144.

${ }^{133}$ McKemmish et al, Records continuum model, 4449.

${ }^{134}$ Ibid.

${ }^{135}$ National Archives, Records management policy, 123.

${ }^{136} \mathrm{McKemmish}$ et al, Records continuum model, 4449.

${ }^{137}$ Ibid.

${ }^{138}$ National Archives, Records management policy.

${ }^{139}$ National Archives, Prototype registry procedure.

${ }^{140}$ Ibid., sections 1,1, 2.2 .

${ }^{141}$ Ibid., 2.

${ }^{142}$ National Archives, Records management policy.

${ }^{143}$ Republic of South Africa, National Archives Act.

${ }^{144}$ National Archives, Registry procedure manual.

${ }^{145}$ Republic of South Africa, National Archives Act, sections 13(1)-13(5).

${ }^{146}$ Ibid.

${ }^{147}$ Ibid., sections 3, 5, 11, 12.

${ }^{148}$ National Archives website.

${ }^{149}$ Republic of South Africa, National Archives Act, sections 3, 5, 13(1)-13(5).

${ }^{150}$ National Archives Act, Managing electronic records.

${ }^{151}$ Bantin, Understanding Data, 5.

${ }^{152}$ Hurley, What, if anything, is records management.

${ }^{153}$ Stuckey, Keepers of the fame.

${ }^{154}$ Flynn, The records continuum model, 80.

${ }^{155}$ Schellnack-Kelly, The role of records management, 97, 191.

${ }^{156}$ Kelly, Over the edge, 48.

${ }^{157}$ Ibid., 41.

${ }^{158}$ Archival Platform, The State of the Archives, 71.

${ }^{159}$ Ibid.

\section{Bibliography}

Allan, K. (ed.) Paper wars: Access to Information in South Africa. Johannesburg: Wits University Press, 2009. 
Archival Platform. State of the Archives: An analysis of South Africa's national archival system. University of Cape Town, 2015.

Australian Capital Territory Records Office. Guideline for records management. Number 8 - Business Continuity and Records Management. Territory Records Office.

Bantin, P. C. Understanding Data and Information Systems for Recordkeeping. London, New York: Neal-Schuman Publishers, 2008

Blouin, F. X. \& Rosenberg, W. G. (eds.) Archives, Documentation and Institutions of Social Memory. Essays from the Sawyer Seminar. Michigan: University of Michigan, 2005.

Brothman, B. "Afterglow: Conceptions of record and evidence in archival discourse." Archival Science 2, no. 3 (2002): 311-342.

Cook, T. "Archival Science and postmodernism: new formulations of old concepts." Archival Science 1, no. 1 (2001): 3-24. Available at: http://www.springerlink.com/content/p52234804/48m463/.

Cook, T. 2011. "The Archive(s) Is a Foreign Country: Historians, Archivists, and the Changing Archival Landscape." The American Archivist, 74, no. Fall/Winter (2011): 600-632. Available at: http://archivists.metapress.com/context/xm04573740262424/fulltext.pdf.

Cook, T. "Remembring the Future. Appraisal of Records and the Role of the Archives in Constructing Social Memory," in Blouin, F. X. and Rosenberg, W. G. Archives, Documentation and Institutions of Social Memory. Essays from the Sawyer Seminar. Michigan: University of Michigan, 2005.

Cook, T. "What is Past is Prologue: A History of Archival Ideas since 1898 and the Future Paradigm Shift." Archivaria 43, Spring (1997): 17-63. Available at: http://210.48.147.73/silibus/pastPrlog.pdf.

Cox, R. J. Archives and Archivists in the Information Age. New York: Neal-Schuman Publishers, 2005.

Cox, R. J. Ethics, Accountability and Recordkeeping in a Dangerous World. London: Facet Publishing, 2006.

Cunningham, A. "Waiting for the Ghost Train: Strategies for Managing Electronic Records Before it is too late." Archival Issues 24, no. 1 (1999): 55-64. Available at: http://minds.wisconsin.edu/handle/1793/45896. 
Department of Arts \& Culture. Annual Report 2009/2010. Pretoria: Government Printer, 2010. Available at:

http://www.dac.gov/publications/annual_report/2009_2010/annual_2009_2010.html.

Department of Arts \& Culture. Annual Report 2011/2012. Pretoria: Department of Arts \& Culture, 2013.

Derrida. J. Archive Fever: A Freudian Impression. Chicago: Chicago University Press, 1996.

Duranti, L. Continuity and Transformation in the Role of Archivists. Unisa Annual Lecture on Archives and Records Management. Unisa Muckleneuk Campus. 1 November 2012

Eastwood, T. (ed.) The Archival Fonds: From Theory to Practice, Ottawa: Bureau of Canadian Archivists, Planning Committee on Descriptive Standards, 1992.

Eichhorn, K. “Archival Genres: Gathering Texts and Reading Spaces.” Invisible Culture 12, (2008):1-10. Available at: http://www.rochester.edu/in_visible-culture

Ellis, J. (ed.) Keeping Archives. Second Edition. Melbourne: DW Thorpe and the Australian Society of Archivists, 1993.

Flynn. S. J. A. "The Records Continuum Model in Context and its implications for Archival Practice.” Journal of the Society of Archivists 22, no. 1 (2010):79-93.

Foucault. M. The Archeology of Knowledge and the Discourse of Language. New York: Pantheon, 1992.

Griffin, A. "Records management capacity assessment system (RMCAS)." Archival Science 4, no. 1 (2004):71-97. Available at: http://www.springerlink.com/content/j811g62402862127.

Harris, V. Exploring Archives: An Introduction to Archival Ideas and Practice in South Africa, Second Edition. Pretoria: National Archives of South Africa, 2000.

Harris, V. S. "Towards symbiosis: An exploration of the relationship between archivist and records manager." Archives News 30, no. 6 (1987):6-14.

Harris, V. S. Archives and Justice: a South African Perspective. Chicago: Society of American Archivists, 2007. 
Healy, P. M. and Palepu, K. G. "The Fall of Enron," Journal of Economic Perspectives 17, no. 2 (2003): 3-26.

Hedstrom, M. “Árchives, Memory and Interfaces with the Past," Archival Science 2, (2002): 21-43.

Hedstrom, M. "Research issues in migration and long-term preservation." Archives and Museum Informatics 11 (1997): 287-292.

Hurley, C. What, if anything, is records management? Records Management Association of Australasia Conference Canberra, 2004. Available at: http://infotech.monash.edu/research/groups/rcrg/publications/ch-what.pdf.

Hunter, G. Developing and Maintaining Practical Archives. New York: Neal Schuman Publishers, 2004.

International Monetary Fund. The IMF's Approach to Promoting Good Governance and Combatting Corruption - A Guide. 2005. Available at: http://www.imf.org/external/no/gov/guide/eng/index.htm.

International Standards Organisation (henceforth ISO). ISO 15489-1: Information and documentation - Records management. Geneva, 2001.

ISO. ISO 15489-2: Information and documentation - Records Management: Guidelines. Geneva, 2001.

ISO. ISO 16175-1:2010 Principles and functional requirements for records in electronic office environments. Part 1: Overview and statement of principles. Geneva: International Standards Organization, 2010.

ISO. ISO 16175-3:2010 Principles and functional requirements for records in electronic office environments. Part 3: Guidelines and functional requirements for digital records management systems. Geneva: International Standards Organization, 2010.

ISO. ISO 16175-2:2011 Principles and functional requirements for records in electronic office environments. Part 2: Guidelines and functional requirements for digital records management systems. Geneva: International Standards Organization, 2011.

Isa, A. M. "Records Management and the Accountability of Governance." PHD:

University of Glasgow, 2009.

Jenkinson, H. A Manual of Archives Administration. Reprint. London: Percy Lund, Humphries and Co, 1996. 
Kelly, G. P. "Over the Edge: The impact of urban sprawl on the City of Ekurhuleni." Masters dissertation: University of Pretoria, 2015.

Ketelaar, E. "Archives of the People, By the People, For the People," South African Archives Journal 34 (1992): 5-16.

Ketelaar, E. "The Panoptical Archive," in Blouin, J. M. \& Rosenberg, W. G. (eds). Archives, Documentation \& Institutions of Social Memory. Essays from the Sawyer Seminar. Michigan: University of Michigan, 2005.

Kirkwood, C. 1994. "Records Management in the public sector and the archival challenges posed by electronic records." South African Archives Journal 36 (1994): 7-16.

Lynch, M. 1999. "Archives in formation: privileged spaces, popular archives and paper trails." History of the Human Sciences 12, no. 2 (1999): 65-87. Available at: http://hhs.sagepub.com/12/2/65.short.

Lyotard, JF. 1984. The Postmodern Condition: A Report on Knowledge. Minneapolis: University of Minnesota.

MacNeil, H. "Archival Theory and Practice: Between Two Paradigms." Archivaria 37, no. Spring (1994): 6-20.

MacNeil, H. Trusting Records - Legal, Historical and Diplomatic Perspectives. Dordrecht: Kluwer Academic Publishers, 2000.

Makhura, M.M. The role of electronic records management in a service organisation. Doctoral thesis: University of Johannesburg, 2001.

Marutha, N.S. Records management in support of service delivery in the public health sector of Limpopo province in South Africa. Masters dissertation: University of South Africa, 2011.

McKemmish, S., Upward, F. H. and Reed, B. "Records Continuum Model" in Encyclopedia of Library and Information Science, $3^{\text {rd }}$ Edition, New York: Taylor and Francis, 2009.

Meijer, A. J. "Transparent government: Parliamentary and legal accountability in an information age" Information Polity 8, no. 1 (2003): 67-78.

National Archives \& Records Service of South Africa (henceforth National Archives) 
National Archives. Prototype Registry Procedure Manual. Pretoria: National Archives \& Records Service of South Africa, 1997.

National Archives. Managing Electronic Records in Governmental Bodies: Policy, Principles and Requirements. Pretoria: National Archives and Records Service of South Africa, 2006.

NARS. Records Management Policy. Pretoria: National Archives \& Records Service of South Africa, 2007.

NARS. Prototype of File Plan for Local Government. Pretoria: National Archives \& Records Service of South Africa, 2009.

NARS website. 2013. General disposal authorities. Available at: http://www.national.archives.gov.za/

Ngoepe, M. S. An exploration of records management trends in the South African public sector: a case study of the Department of Provincial and Local Government. Masters Dissertation, University of South Africa, 2008.

Ngoepe, M. S. "The role of records management as a tool to identify risks in the public sector in South Africa." South African Journal of Information Management 16, no. 1 (June): 615-623.

Ngulube, P. "Archival Appraisal and the Future of Historical Research in Southern Africa." South African Historical Journal 45, no. 1 (2001): 249-265.

Nesmith, T. "Re-exploring the continuum, rediscovering archives." Archives and Manuscripts 36, no. 2 (2008): 34-53.

Office of the Auditor-General of South Africa. Consolidated General Report on the audit outcomes of local government 2010-2011. Pretoria: Auditor-General, 2012.

Oliver, G. and Foscarini, F. Records Management and the Information Culture: Tackling the People Problem. London: Facet Publishing, 2014.

Qwabe, B.R. "Realising South Africa's Vision 2030," Administratio Publico 21, no. 2 (2013): 21-36.

Republic of South Africa (RSA). The Constitution of the Republic of South Africa Act no. 108 of 1996. Pretoria: Government Printer, 1996.

RSA. National Archives and Records Service Act of South Africa, no. 43 of 1996. Pretoria: Government Printers, 1996. 
Research Focus and Content-at-Work. The demand and supply of skills in library and information services, archival services and records management for the Department of Arts and Culture. 2010.

Roper, M. \& Millar, L. (ed.). Managing Public Sector Records: A Training Programme. An Introduction to the Management of Public Sector Records Study Programme. London: International Records Management Trust, 1999.

Schellenberg, T. R. Modern Archives; Principles and Techniques. Chicago: University of Press, 1956.

Schellenberg, T. R. The Management of Archives. New York: Colombia University Press, 1965.

Schellnack-Kelly, I. S. The role of records management in governance-based evidence, service delivery and development of South African communities. Doctoral thesis: University of South Africa, 2013.

Schwartz, J. M. 'Records of simple truth and precision.' Photography, Archives and the Illusion of Control, in Blouin, J. M. \& Rosenberg, W. G. (eds). Archives, Documentation \& Institutions of Social Memory. Essays from the Sawyer Seminar. University of Michigan, 2005.

Stapleton, R. “Jenkinson and Schellenberg: A Comparison.” Archivaria 17 (1983-1984): 75-85.

Stuckey, S. "Keepers of the fame? The Custodial Role of Australian Archives - its history and its future." The Records Continuum. 1994. Available at: http://www.ourhistory.naa.gov.au.

Tempelhoff, J. W. N. "A history of the Waterlit Collection (1974-1999): A hard copy collection research collection on water studies and its digital catalogue," Journal for Contemporary History 40, no. 1 (2015):162-194.

Trace, C. B. 2002. "What is recorded is never simply 'what happened': record keeping in modern organizational culture." Archival Science 2, no. 1 (2002): 137-159. Available at: http://www.springerlink.com/content/711gx364707045g0/ (Accessed 5 December 2011).

Venter, L. "National Archives and Records Service requirements for the management of electronic records in the public sector: an archivist's perspective on records management versus storage management," Archives News 50, no. 2 (2007): 22-26. 
United Nations Human Rights Office of the High Commissioners for Human Rights (UNHCHR), Human Rights and the Millennium Development Goals in Practice: A review of country strategies and reporting. New York, Geneva, United Nations, 2010.

United States General Accounting Office. Best Practices Methodology. A new approach for improving government operations. Washington DC: US General Accounting Office, 1995.

Upward, F. "Continuum Mechanics and Memory Banks: (1) Multi-polarity." Archives and Manuscripts 33, no. 1 (2008): 84-109.

Upward, F. and Stillman, L. "Community Informatics and the Information processing continuum." Peer-reviewed conference paper for the conference proceedings of Constructing and Shaping Memory: Community informatics, identity and empowerment, CIRN, Prato, 9-10 October, 2006.

World Bank. Strengthening the effectiveness of aid lessons for donors. Washignton: World Bank Publication, 1995. 